\title{
STRATEGIES USED BY UNDERGRADUATE ENGLISH- MAJORED STUDENTS IN ORAL COMMUNICATION
}

\author{
Le Van Tuyen*, Huynh Thi An, Tran Kim Hong \\ Ho Chi Minh City University of Technology (HUTECH) \\ 475A-Dien Bien Phu Street, Binh Thanh District, Ho Chi Minh City-Vietnam
}

Received 16 December 2019

Revised 28 January 2020; Accepted 14 February 2020

\begin{abstract}
Communication strategies (CSs) play a significant role in enabling EFL students to achieve a higher level of English proficiency and good ability in oral communication. Helping both EFL teachers and students gain awareness of CSs is essential in the Vietnamese context. This study, therefore, aimed to explore the most commonly used strategies in English oral communication among English-majored students at Ho Chi Minh City University of Technology (HUTECH), Vietnam. Two instruments were employed to collect both qualitative and quantitative data, namely (1) the questionnaire and (2) the focus group with the participation of 213 English-majored sophomores, juniors and seniors. The findings of the study revealed that the most commonly-used speaking strategies are 'fluency-oriented', 'message reduction and alteration', and 'negotiation for meaning while speaking', and that the students used achievement strategies more often than reduction ones; and the most commonly-used listening strategies are 'negotiation for meaning while listening', 'non-verbal' and 'scanning'. The findings also revealed that there are no significant differences in the use of CSs among the three academic levels of students. It is expected that the findings of the study would partly contribute to the enhancement of communicative competence $(\mathrm{CoC})$ and the use of CSs among students at HUTECH in particular and at the Vietnamese tertiary level in general.

Keywords: communicative competence, communication strategies, English-majored students, academic levels, Vietnamese context
\end{abstract}

\section{Introduction}

The process of integration into the region and the world requires Vietnam to train high quality manpower. It is the duty of universities to provide most of the skilled manpower resources to society. Regional and global competition and the era of industry 4.0 entail students' integration of their language skills and their specialized knowledge to compete on the demanding job market and keep up with the world. For students, it is not easy to accomplish this task. After many years of learning English both at secondary school

* Corresponding Author: Tel.: 84-982362727

Email: lv.tuyen@hutech.edu.vn and at university, a majority of Vietnamese students, after graduation, can neither speak English fluently nor confidently (Tran, 2013). Their real level of English cannot be significantly improved and is still very far from the requirements of their future jobs (Le, 2013). "Who or what is to blame for this deficiency, teachers, non-native speaking context, or students themselves?" Or "Should other reasons be discovered?"

Second or foreign language acquisition and the development of $\mathrm{CoC}$ require language students to participate in real-life interaction, which demands ample efforts and abilities to deal with unexpected situations and problems when interacting with both native and nonnative English speakers (Peloghities, 2006). 
Thus, CSs play an integral part for students to cope with speaking and listening problems in the process of language acquisition. Nevertheless, most of the EFL students in Vietnam are not aware of the importance of using CSs; and their use of strategies in English oral communication is still limited (Le, 2018). Therefore, raising students' awareness of the use of CSs is a must.

According to Stern (1983), to have indepth understanding of the use of CSs, studies should be conducted in different contexts, under different language learning conditions, and at different levels of language proficiency. So far CSs seem to have been a major area of investigation and exploration in the field of second or foreign language acquisition. That is because these strategies do not only help overcome problems but they can also significantly contribute to improving and building up strategic competence (SC) for English users (Ounis, 2016); especially, different learning contexts may have different impact on students' use of CSs and their communicative performance (Kitajima, 1997). Nonetheless, a review of the relevant literature revealed that studies with respect to the use of CSs by Vietnamese tertiary students are quite few. To fill this gap, this study aims to investigate the use of strategies in oral communication by English-majored students at tertiary level of Vietnam. More specifically, it attempts (1) to explore the common strategies used to deal with speaking and listening skills among English-majored students at $\mathrm{Ho}$ Chi Minh City University of Technology (HUTECH); and (2) to examine whether there are significant differences in the use of CSs among three academic levels, namely sophomores, juniors, and seniors.

Based on the objectives, the current study attempted to answer the two following questions:

1. What are the most common strategies used in oral communication by Englishmajored students at HUTECH?
2. What are the differences in the use of strategies in oral communication among three academic levels of English-majored students at HUTECH?

\section{Literature review}

\subsection{Strategic competence}

Strategic competence is one of the components of $\mathrm{CoC}$ which was proposed explicitly by Canale and Swain (1980) and Bachman (1990) or implicitly by Hymes (1967), CEFR (2001) and Littlewood (2011). Accordingly, all the components of $\mathrm{CoC}$ mention both knowledge of the contents and ability to use it. For example, sociolinguistic competence refers to knowledge and ability to use the language appropriately in different social contexts. SC refers to the ability to use verbal and non-verbal strategies to compensate for breakdowns in communication due to insufficient grammatical and sociolinguistic competence, or to enhance the effectiveness of communication (Canale \& Swain, 1980). It is an important part of all communicative language use. SC is regarded as a capacity that puts language competence into real communication contexts. It may include strategies which are not linguistic (Bachman, 1990). It consists of such strategies as paraphrasing grammatical forms, using repetition, structures, themes, reluctance, avoiding words, guessing, changing register and style, modifying messages, and using gestures and facial expressions, fillers and comprehension checks, etc. (Canale \& Swain, 1980).

It is undoubted that SC not only emphasizes the use of CSs which can help to overcome deficiency of language knowledge in a particular area but the use of all types of CSs in different communication contexts (CEFR, 2001). SC is considered to be important for EFL language students at all levels, especially for students of low English proficiency. It may be used as solutions for them to deal with problems or challenges in communication. 


\subsection{Communication strategies}

\subsubsection{Defining communication strategies}

When the concept "communicative competence" was introduced, components related to it were also developed by scholars and researchers. One of its components is SC which mentions CSs. CSs are seen as tools for negotiating the meaning between two interlocutors based on communication desire and as facilitators in the process of communicating orally in L2 (Tarone, 1981). A variety of definitions of CSs were also proposed. From interactional perspective, according to Tarone (1980), Canale (1983) and Nakatani (2006), CSs refer to the agreement with a meaning through mutual attempts of two interlocutors in communication situations. From psycholinguistic perspective, Corder (1983) defined a CS as a systematic technique employed by a speaker to express the meaning when he or she is faced with some difficulty or problems. Similarly, according to Færch and Kasper (1984), CSs are related to individual language users' experience of communicative problems and solutions they pursue, and to an individual's attempt to find a way to fill the gap between their communication effort and immediate available linguistic resources (Maleki, 2007). According to Ellis (1994), CSs refer to the approach that is used by language students to deal with the deficiency of their interlingual resources.

Based on the above definitions and the two perspectives: the interactional view reflecting meaning-negotiating activities and psycholinguistic one reflecting problemsolving ones, it can be inferred that CSs are both verbal or non-verbal means or tools employed by two or more interlocutors to negotiate meaning or overcome difficulties which they experience in terms of both speaking and listening skills so that they can agree on a communicative purpose.

\subsubsection{Taxonomies of communication strategies}

As mentioned above, scholars and researchers have conducted studies on CSs from two major perspectives: the interactional view and psycholinguistic view. Some scholars support the former (e.g., Tarone, 1980); meanwhile, others support the latter (e.g., Faerch \& Kasper, 1983). That is why taxonomies of CSs also vary significantly (Rababah, 2002). Researchers have confirmed several major taxonomies of CSs as follows: (a) Tarone's taxonomy (1983) consists of five main categories: (1) Paraphrase including approximation, word coinage and circumlocution; (2) Transfer including literal translation and language switch; (3) Appeal for assistance which means that the learner asks for the correct term or structure; (4) Mime refers to the learner's use of non-verbal strategies to replace the meaning structure; and (5) Avoidance consisting of two subcategories: topic avoidance and message abandonment; (b) Bialystok's Taxonomy (1983) contains three main categories: (1) L1-based strategies, (2) L2-based strategies and (3) paralinguistic strategies; (c) Faerch and Kasper (1983) proposed two categories of strategies in general for solving a communication problem: (1) avoidance strategies and (2) achievement strategies. Avoidance strategies include formal reduction strategies and functional reduction strategies. Achievement strategies comprise compensatory strategies and retrieval strategies; (d) Corder's (1983) taxonomy includes two categories: (1) message adjustment strategies and (2) resource expansion strategies; (e) Dornyei and Scott's taxonomy (1995) seems to be a summary of all the taxonomies available in CS research (Rababah, 2002). Their taxonomy includes three main categories: (1) direct strategies including resource deficitrelated strategies, own-performance problemrelated strategies, and other-performancerelated strategies; (2) interactional strategies including resource deficit-related strategies, own-performance problem-related strategies, and other-performance-related strategies; and (3) Indirect strategies including processing time pressure-related strategies, ownperformance problem-related strategies, 
and other-performance-related strategies;

(f) Rababah's taxonomy (2002) includes

(1) L1-based strategies including literal translation and language switch; (2) L2-based strategies including avoidance strategies, word-coinage, circumlocution, self-correction, approximation, mumbling, L2 appeal for help, self-repetition, use of similar-sounding words, use of all-purpose words, and ignorance acknowledgement.

It can be concluded that all CSs seem to share three main features as stated by Bialystok (1990): (a) Problematicity - this refers to strategies adopted by speakers when perceived problems may interrupt communication;(b)Consciousness - this refers to speakers' awareness of employing the strategy for a particular purpose which may lead to an intended effect; and (c) Intentionality - this refers to speakers' control over those strategies so that particular ones may be selected from a range of options and deliberately applied to achieve certain effects. Moreover, CSs have been developed in different stages with different types. They may be positive or compensatory strategies and negative or reduction strategies (Willems, 1987). They may be L1 - or L2-based, implicit or explicit, verbal or non-verbal, and linguistic or non-linguistic strategies which are employed to support speakers in dealing with problems in oral communication which contains both speaking and listening skills. Nonetheless, it seems that no researchers identified which strategies are for coping with speaking problems and which ones are for coping with listening problems except for Nakatani's (2006) strategies which were investigated and developed from interactional perspective.

\section{Research methodology}

\subsection{Participants}

This study was conducted at Ho Chi Minh City University of Technology (HUTECH) in Vietnam. The participants of the study consisted of three cohorts of English-majored students who were in their second, third and fourth academic years. The total number of participants was 213 students including cohort 1: 75 sophomores (second-year students), cohort 2: 69 juniors (third-year students) and cohort 3: 69 seniors (fourth-year students); 108 of them are female $(50.7 \%)$; and 105 of them are male (49.3\%). Their ages range from 19-20 (34.7\%), 21-23 $(62.0 \%)$, and 24-over (3.3\%). Because they major in English, their English proficiency may range from intermediate to advanced levels. They study English in class 4 hours a day in average with both non-native and native English speaking teachers. Especially, they have various opportunities to communicate with foreigners outside the classroom.

\subsection{Instruments}

The current study collected both quantitative and qualitative data, so two instruments were employed: (a) the closeended questionnaire was used for collecting quantitative data. The questionnaire could help obtain information from a large number of students' knowledge, perceptions and beliefs with respect to the use of CSs (Burns, 1999; Bulmer, 2004). The questionnaire was adopted from Nakatani (2006). It consisted of three parts. The first part included 3 items used to explore demographic information of the students. The second part included 8 categories with 32 items used to explore the students' perceptions of the use of OCSs in speaking and the last part consisted of 7 categories with 26 items used to explore the students' perceptions of the use of OCSs in listening (Refer to Appendix A). The questionnaire used five-point Likert scale ranging from never, rarely, sometimes, often to always; and (b) to obtain triangulation of data for the study, the focus group was used for collecting qualitative data. The focus group with 16 questions (Refer to Appendix B) was used after the survey questionnaire to help interpret and obtain more insights (Krueger \& Casey, 2000) from the students' perceptions of strategy use and explore their personal experiences in oral communication. 
The reliability of the questionnaire was tested through Cronbach's Alpha with the coefficient of .840 for 32 speaking strategies and .823 for 26 listening ones, which proved a highly acceptable internal consistency. For convenience reasons, the questionnaire items were translated into Vietnamese and the interview questions were designed in Vietnamese and later translated into English.

\subsection{Nakatani's (2006) oral communication strategy inventory (OCSI)}

One of the latest inventories which were developed by researchers for investigating CSs is Nakatani's (2006). This inventory has been highly estimated and widely used by many researchers because of its details, reliability and validity. The OCSI is divided into 2 parts. The first part consists of 8 categories with 32 strategies (variables) for coping with speaking problems, and the second part consists of 7 categories with 26 strategies (variables) for coping with listening problems (pp.163-164). Strategies for coping with speaking problems include (a) social affective strategies, (b) fluency orientation, (c) meaning negotiation, (d) accuracy orientation, (e) message reduction and alteration, (f) nonverbal strategies, $(\mathrm{g})$ message abandonment, and (h) attempt-to-think-in-English. Strategies for coping with listening problems include (a) meaning negotiation (b) fluency maintenance, (c) scanning, (d) getting-the-gist strategies, (e) non-verbal strategies, (f) less-active-listener strategies, and (g) word-oriented strategies (Refer to Table 1).

Table 1. Nakatani's (2006) oral communication strategy inventory

\begin{tabular}{ccc}
\hline No & Categories of speaking strategies & Categories of listening strategies \\
\hline $\mathbf{1}$ & Social affective & Negotiation for meaning \\
$\mathbf{2}$ & Fluency-oriented & Fluency-maintaining \\
$\mathbf{3}$ & Negotiation for meaning & Scanning \\
$\mathbf{4}$ & Accuracy-oriented & Getting-the-gist \\
$\mathbf{5}$ & Message reduction and alteration & Non-verbal \\
$\mathbf{6}$ & Non- verbal & Less-active-listener \\
$\mathbf{7}$ & Message abandonment & Word-oriented \\
$\mathbf{8}$ & Attempt-to-think-in-English & \\
\hline
\end{tabular}

Source: Nakatani (2006, p.161)

Literature shows that previous studies which employed Nakatani's (2006) OCSI were conducted in different EFL contexts like in Taiwan (Chen, 2009), in Iran (Mirzaei \& Heidari, 2012; Rastegar \& Goha, 2016), in Turkey (Sevki \& Oya, 2013), in Malaysia (Zulkurnain \& Kaur, 2014), in Tunisia (Ounis, 2016), and in Thailand (Chairat, 2017). The findings of these previous studies confirmed that Nakatani's OCSI is a reliable tool. This inventory has a clear and detailed factor structure (Zulkurnain \& Kaur, 2014). As calculated by Nakatani's study, the Alpha coefficient for 32 speaking strategies was .86 (p.154) and for 26 listening ones was .85 (p.156), which indicates a highly acceptable internal consistency. The OCSI was developed

for the Japanese students who learn EFL like Vietnamese ones. The two contexts may be considered to be similar because both Japan and Vietnam are in the Expanding Circle. Nonetheless, one particular concern is that the constructs of the questionnaire developed by Nakatani (2006) need to be further clarified and statistically validated to convince the end-users of their reliability and validity (Mei \& Nathalang, 2010). More studies need to be conducted using this inventory so that more insightful findings from different EFL contexts could enrich our understanding of the use of English OCSs and contribute more to EFL teaching and learning; and strategies should be investigated in accordance with the culture they are used in (Yaman \& Özcan, 2015). Vietnam has 
witnessed its tremendous growth in the number of students who learn EFL; and certainly an investigation into students' strategy use in oral communication is of vital importance and necessity. From the interactional perspective, the current study employed Nakatani's OCSI as the tool for investigating the use of strategies in oral communication of Vietnamese tertiary students.

\subsection{Data collection and analysis procedures}

Regarding data collection procedure, firstly, to collect quantitative data from the participants, one of the researchers came to each class to introduce the purpose and significance of the study. The instruction of how to complete the questionnaire was clarified and explained carefully to them. Questionnaire copies were administered to 225 English-majored students. They were randomly selected from 15 classes with the ratio of 15 students perclass. The students were asked to complete the questionnaire and return them within three days. After three days, 220 students returned the questionnaire copies, accounting for $97.7 \%$. However, 7 copies were not completed as required; therefore, the final number of questionnaire copies was 213. Later, 24 (8 from each group) among 213 students were invited to participate in the focus group. Three focus groups for three academic levels were conducted. Each interview lasted about 60 minutes. During the interviews, an interview sheet was used for one group. Two researchers took part in the interviews. One asked questions, guided, facilitated and gave suggestions; and the other took notes of responses.

Regarding data analysis procedure, to analyze the data obtained from the questionnaire, SPSS 22.0 was employed so that descriptive statistics including mean (M), and standard deviation (St. D) of each item and category were processed. Based on calculated interval coefficient for four intervals in five points $(5-1=4)$, intervals with the range of $0.80(4 / 5)$ were arranged. The following criteria in the Likert type scale were used to interpret the data: never (1.00 $1.80)$; rarely $(1.81-2.60)$; sometimes $(2.61$
- 3.40); often (3.41 - 4.20); always (4.21 5.00). In addition, one-way ANOVA tests were carried out to find out if differences in the use of strategies existed among the three academic levels; whereas content analysis was employed to deal with qualitative data; and the students were coded as SO-1 to SO-8 for sophomores, JU-1 to JU-8 for juniors, and SE- 1 to SE- 8 for seniors.

\section{Results and discussion}

\subsection{Strategies used in oral communication}

Research question 1 attempted to explore the most common strategies used by English majored students in dealing with oral communication. The results of research question 1 presented and interpreted below were based on categories of strategies used in speaking and listening.

\subsubsection{Strategies used in speaking}

Both quantitative and qualitative data collected revealed that the first three categories of strategies used with the highest frequency were 'fluency-oriented', 'message reduction and alteration' and 'negotiation of meaning'.

The data displayed in Table 2 reveal that the fluency-oriented strategies are the top ranking strategies with $\mathrm{M}=3.72$ and St. D $=.641$, which means that the students often paid attention to these strategies when they communicate with someone. Particularly, they paid most attention to rhythm, intonation and pronunciation $(\mathrm{M}=4.01)$. The data collected from the three focus groups also revealed that among 24 students participating in the interviews, 20 of them (83\%) expressed that when communicating with others they often paid attention to pronunciation. More interestingly, all the 8 juniors said that they were often conscious of the importance of pronunciation. For example, SO-5 said, "I pay attention to intonation and pronunciation which is very important for us to understand the message. If we pronounce words wrongly, the listener can't understand." 
Table 2. Descriptive statistics and rank of fluency-oriented strategies

\begin{tabular}{|c|c|c|c|c|}
\hline No & Items & Rank & Mean & St. D \\
\hline & Fluency-oriented strategies & 1 & 3.72 & .641 \\
\hline 7 & I pay attention to my rhythm and intonation. & & 3.90 & 1.050 \\
\hline 8 & I pay attention to my pronunciation. & & 4.01 & .992 \\
\hline 9 & I pay attention to the conversational flow. & & 3.64 & .918 \\
\hline 10 & I change my way of saying things according to the context. & & 3.53 & 1.025 \\
\hline 11 & I take my time to express what I want to say. & & 3.32 & .954 \\
\hline 12 & I try to speak clearly and loudly to make myself heard. & & 3.89 & 1.041 \\
\hline
\end{tabular}

The findings of the study revealed that most of the students might recognize the importance of correct pronunciation of L2 words in communication as stated by Derwing and Munro (2015) that the inability to produce intelligible pronunciation of words and utterances can lead to both misunderstanding and frustration on the part of listeners. That is also the reason why they tried to produce accurate pronunciation of the target language or spoke clearly and loudly to make themselves heard. In addition, they might want the conversation to go smoothly and the listener to understand them clearly. Undoubtedly, it is essential for foreign language students to adopt fluency-oriented strategies in conversations (Dornyei \& Scott, 1995). This finding is consistent with that of Zulkurnain and Kaur (2014) showing that the category of fluency-oriented strategies was among the three most commonly-used categories among EFL tertiary students.

Regarding 'message reduction and alteration' and 'negotiation for meaning' strategies, the data displayed in Tables $3 \& 4$ show that the former rank second and the later rank third with $\mathrm{M}=3.65$ and 3.60, and St. $\mathrm{D}=$ .727 and .703 respectively; and most strategies of the two categories were often used by the students with mean scores from 3.43 to 4.10 , except item 24 with $\mathrm{M}=3.38$. Remarkably, it can be seen that the strategy "I use words which are familiar to me." (Item 23) obtained the highest mean score $(M=4.10)$. The finding also revealed that most of the students often paid attention to the listener's reaction to their speech (item 15) with $M=3.94$. The findings of the questionnaire are consistent with the data collected from the three interviews revealing that among 24 students participating in the interviews, 22 out of 24 $(92 \%)$ respondents expressed that they often used simple expressions or words which were familiar to them while speaking. However, two of them expressed that it depended on situations. For example, "I try to use as many simple words as possible because I don't want other speakers to ask me to repeat my ideas. I often use familiar words but sometimes I use difficult words to make my speech more interesting (SO-1); or "It depends on contexts. I use simple, common phrases or words for informal speaking situations. I use new, academic words for in-class presentation and discussion to make my arguments more persuasive and gain higher scores (JU-3)."

Table 3. Descriptive statistics and rank of 'message reduction and alteration' strategies

\begin{tabular}{|c|c|c|c|c|}
\hline No & Items & Rank & Mean & St. D \\
\hline \multicolumn{2}{|r|}{ 'Message reduction and alteration' strategies } & 2 & 3.65 & .727 \\
\hline 22 & I reduce the message and use simple expressions. & & 3.48 & 1.044 \\
\hline 23 & I use words which are familiar to me. & & 4.10 & .989 \\
\hline 24 & $\begin{array}{l}\text { I replace the original message with another message because } \\
\text { incapable of executing my original intent. }\end{array}$ & & 3.38 & 1.046 \\
\hline
\end{tabular}


Table 4. Descriptive statistics and rank of 'negotiation for meaning while speaking' strategies

\begin{tabular}{|c|c|c|c|c|}
\hline No & Items & Rank & Mean & St. D \\
\hline \multicolumn{2}{|r|}{ 'Negotiation for meaning while speaking' strategies } & 3 & 3.60 & .703 \\
\hline 13 & I make comprehension checks to ensure the listener understands & to say. & 3.43 & 1.060 \\
\hline 14 & I repeat what I want to say until the listener under & & 3.47 & 1.002 \\
\hline 15 & While speaking, I pay attention to the listener's reaction & & 3.94 & .937 \\
\hline 16 & I give examples if the listener doesn't understand what & & 3.56 & 1.124 \\
\hline
\end{tabular}

The findings of the study are consistent with those of Ounis's (2016) that revealed that the students might consider those strategies the most practical and effective ones that could be used to deal with speaking problems. More specifically, most of the students tried to use simple expressions or familiar words in communication. They wanted the listener to understand what they said. The use of the 'negotiation of meaning' strategies is the attempt of students to overcome comprehension difficulties so that incomprehensible or partly comprehensible input becomes comprehensible (Foster \& Ohta, 2005). They needed to understand and be understood with clarity; obviously, they might recognize that these strategies have a positive effect on L2 learning (Nakatani, 2010); and to maintain their interaction and avoid a communication breakdown, they might often know how to conduct modified interaction and check listeners' understanding of their intentions (Nakatani, 2006). It can be concluded that the students often encounter problems due to their lack of linguistic resources; therefore, they usually use their existing knowledge consciously with the intention of conveying a comprehensible message and achieving their communicative goal (Faerch \& Kasper, 1983).

The next 3 categories of strategies which obtained medium frequency were 'nonverbal', 'social affective' and 'attempt to think in English' strategies. In terms of the use of 'non-verbal' category, this category of strategies ranked $4^{\text {th }}$ as shown in Table 5 with $\mathrm{M}=3.57$ and St. $\mathrm{D}=.887$. It means that the students often made eye contact and used body language in oral communication with $\mathrm{M}=3.57$ and 3.58 respectively. More interestingly, according to the data collected from the focus group interviews, 24 respondents $(100 \%)$ said that they used body language in communication. For instance, SE-1 said, "When talking to someone, I often make eye contact with him or her to show that I'm interested in the talk. If I don't know how to express my ideas, or if I realize that the listener doesn't understand me, I often use gestures and facial expressions."

Table 5. Descriptive statistics and rank of non-verbal strategies

\begin{tabular}{lcccc}
\hline No & Items & Rank & Mean & St. D \\
\hline & Non-verbal strategies while speaking & 4 & 3.57 & .887 \\
$\mathbf{2 5}$ & I try to make eye contact when I am talking. & & 3.57 & 1.145 \\
$\mathbf{2 6}$ & I use gestures and facial expressions if I can't express myself. & & 3.58 & 1.041 \\
\hline
\end{tabular}

Ranking $5^{\text {th }}$ is the category of 'social affective' strategies with $\mathrm{M}=3.50$ and St. $\mathrm{D}=.659$. As it can be seen in Table 6 , the students often tried to encourage themselves and give good impression to the listener with $\mathrm{M}=3.85$ and 3.77. Although they felt anxious when speaking to someone, they often tried to relax to maintain the conversation. However, not many students reported that they enjoyed conversations and took risks in speaking English (item $2 \& 5$ ) with $\mathrm{M}=3.07 \& 3.33$ respectively. Regarding qualitative data, 24 students $(100 \%)$ expressed that they faced difficulties in speaking and listening; and they 
always tried to overcome those difficulties. For example, SO-6 reported, "I feel shy, lack confidence and lack understanding of other speakers' messages. However, I still try to relax although it is not easy."

Table 6. Descriptive statistics and rank of social affective strategies

\begin{tabular}{|c|c|c|c|c|}
\hline No & Items & Rank & Mean & St. D \\
\hline & Social affective strategies & 5 & 3.50 & .659 \\
\hline 1 & I try to relax when I feel anxious. & & 3.56 & 1.158 \\
\hline 2 & I try to enjoy the conversation. & & 3.07 & 1.117 \\
\hline 3 & I try to give a good impression to the listener. & & 3.77 & .979 \\
\hline 4 & I actively encourage myself to express what I want to say. & & 3.85 & .974 \\
\hline 5 & I don't mind taking risks even though I might make mistakes. & & 3.33 & 1.238 \\
\hline 6 & I try to use fillers when I cannot think of what to say. & & 3.41 & 1.232 \\
\hline
\end{tabular}

With respect to 'attempt to think in English' category, it ranks $6^{\text {th }}$ with $\mathrm{M}=3.41$ and St. $\mathrm{D}=.908$. The data displayed in Table 7 show that more students think of what they want to say in L1 and then construct the English sentence (item 32); and fewer of them think first of a sentence they already know in English (item 31) with $\mathrm{M}=3.45 \& 3.38$ and St. D $=1.229 \& 1.113$ respectively. The data collected from the focus groups revealed that among 24 respondents, 16 of them (66\%) expressed that they thought of what they wanted to say in L1 first. For example, SO-6 reported, "I try to think in Vietnamese first then translate the sentence into English, especially with complicated messages."

Table 7. Descriptive statistics and rank of 'attempt to think in English' strategies

\begin{tabular}{ccccc}
\hline No & Items & Rank & Mean & St. D \\
\hline \multirow{3}{31}{} & I think first of a sentence I already know in English and then try to change it & 3.38 & 1.113 \\
& $\begin{array}{c}\text { to fit the situation. } \\
\mathbf{3 2}\end{array}$ & $\begin{array}{c}\text { I think of what I want to say in my native language and then construct the } \\
\text { English sentence. }\end{array}$ & 3.45 & 1.229 \\
\hline
\end{tabular}

Oral communication is accomplished via the use of verbal strategies or in combination with non-verbal strategies. Successful communication involves the integration of both strategies. The findings of the study are in line with those of Sevki and Oya (2013) showing that English-majored students understand more about the role of non-verbal strategies. They used body language to deal with overall problems in L2 they encounter while speaking. They made eye contact when they were talking or used gestures and facial expressions to maintain the conversation. That is because verbal communication is not sufficient for successful communication in the foreign language (Stam \& McCafferty,
2008). Many ways can be employed in communication between two or more people. Using vocabulary is one of these ways. Gestures and body language are often even more important than words (Leaver, Ehrman \& Shekhtman, 2005) and can be used to convey the meaning to deal with problems so that interlocutors can maintain a conversation. The findings of the study also revealed that not many students took risks speaking English. That is because they might be afraid of making mistakes; they might have a weak or moderate language ego. However, according to Brown (2002), successful EFL students must be risk takers. Risk-taking is considered one of the most important and successful strategies EFL 
students should use. Disappointingly, many students reported that they often thought first of a sentence in L1 and then translated into L2. By doing so, the students may gradually lose the habit of thinking in L2. It can be considered 'dangerous' in learning a foreign language. Those students might be less able or low proficient ones. Their habit of thinking in L1 might be formed when they first started learning English.

The most surprising findings of the study are displayed in Tables 8 and 9 below. That is because the frequency of 'accuracy-oriented' and 'message abandonment' are the least frequently reported categories of strategies with $\mathrm{M}=3.20 \& 2.74$ and St. $\mathrm{D}=.685 \& .779$ respectively. The students did not pay much attention to linguistics-related strategies. They did not often follow the rules that they had learned, or emphasize the subject and the verb of a sentence with $\mathrm{M}=2.90 \& 3.02$ respectively. More interestingly, not many of the students reported that they often abandoned messages. This is a positive sign that must be recognized in the context because the students could realize that linguistics is not the only factor that helps make communication in L2 effective. They neither often left a message unfinished due to language difficulty, nor gave up when they could not make themselves understood and know what to say with $\mathrm{M}=$ $2.45 \& 2.59$. The data collected from the focus group interviews also revealed that 19 out of 24 respondents $(79 \%)$ often maintained the conversation in spite of problems related to linguistics. For instance, some students expressed, "I often try to find simple phrases or words to continue the conversation. If the speaker still doesn't understand, I'll change the topic (JU-4); "I rarely quit the conversation. If I don't understand, I ask the speaker some questions to clarify the message, or use simple expressions to convey the information (SE-1)."

Table 8. Descriptive statistics and rank of accuracy-oriented strategies

\begin{tabular}{|c|c|c|c|}
\hline No & Items & Mean & St. D \\
\hline & Accuracy-oriented strategies & 3.20 & .685 \\
\hline 17 & I pay attention to grammar and word order during conversation. & 3.03 & 1.031 \\
\hline 18 & I notice myself using an expression which fits a rule that I have learned. & 2.90 & 1.087 \\
\hline 19 & I correct myself when I notice that I have made a mistake. & 3.55 & 1.078 \\
\hline 20 & I try to emphasize the subject and verb of the sentence. & 3.02 & 1.027 \\
\hline 21 & I try to talk like a native speaker. & 3.47 & 1.155 \\
\hline
\end{tabular}

Table 9. Descriptive statistics and rank of 'message abandonment' strategies

\begin{tabular}{lcccc}
\hline No & Items & Rank & Mean & St. D \\
\hline & 'Message abandonment' strategies & 8 & 2.74 & .779 \\
$\mathbf{2 7}$ & I leave a message unfinished because of some language difficulty. & 2.79 & .976 \\
$\mathbf{2 8}$ & I ask other people to help when I can't communicate well. & 3.15 & 1.211 \\
$\mathbf{2 9}$ & I give up when I can't make myself understood. & 2.45 & 1.271 \\
$\mathbf{3 0}$ & I abandon the execution of a verbal plan and just say some words when I don't & 2.59 & 1.200 \\
& know what to say. & & \\
\hline
\end{tabular}

The findings of the study are in line with those of Chen (2009) and Yaman and Özcan (2015) revealing message abandonment strategies are the least frequently used. It can be seen that many students did not want to reduce the communication task. They attempted to use achievement strategies so that they could solve problems in communication. The findings of the study are in line with the viewpoint of Larsen-Freeman and Long (1991) showing that the EFL students' ability to maintain a conversation is a very valuable skill because they can benefit from receiving additional modified input. Such maintenance 
skill is one of the major objectives for EFL students who regularly employ strategies in oral communication.

In conclusion, there is always a mismatch and a gap between communicative goals and linguistic resources among non-native English speakers. They cannot avoid problems related to linguistic competence during the process of communication. It is undoubted that the students in the context, though, did not use all strategies, they tried to deal with communication problems due to their deficient resources in L2 through the use of various strategies. It can be concluded that the three most commonly-used speaking strategies are 'fluency-oriented', 'message reduction and alteration', and 'negotiation for meaning while speaking'; and that the students used achievement strategies more frequently than reduction ones. They attempted to bridge the gap that exists between the non-native speakers' linguistic competence in L2 and their communicative needs (Rababah, 2004). It can be said that the students wanted to develop communicative proficiency by trying to employ strategies in oral communication to compensate for inadequacies in their knowledge of L2.

\subsubsection{Strategies used in listening}

Listening in English is considered an active, receptive skill requiring students to employ a variety of strategies. The data displayed in the tables below show that English-majored students at HUTECH employed different strategies to deal with listening skills.

The data in Table 10 show that category of 'negotiation for meaning while listening' strategies ranks first. Among the 7 categories of listening strategies investigated in the study, this category was the most frequently used by the students in the context with $\mathrm{M}=$ 3.76 and St. $\mathrm{D}=.748$. More specifically, the strategy that obtained the highest frequency is asking for repetition when they could not understand what the speaker said (item 1) with $\mathrm{M}=3.80$. The other three strategies of this category were also obtained a high frequency (item 2, 3, 4) with $\mathrm{M}=3.78,376$, and 3.78 respectively. The data collected from the focus groups also revealed that all of the 24 respondents used 'negotiation for meaning' strategies to deal with listening problems. For example, 'I ask the speaker some questions to clarify messages, or sometimes I ask the speaker to speak slowly...(JU-5); “...when I can't understand, I ask the speaker to use simpler and more common words; or ask him or her to repeat the message (SE-7).

Table 10. Descriptive statistics and rank of 'negotiation for meaning while listening' strategies

\begin{tabular}{ccccc}
\hline No & Items & Rank & Mean & St. D \\
\hline & 'Negotiation for meaning while listening' strategies & 1 & 3.76 & .748 \\
$\mathbf{1}$ & I ask for repetition when I can't understand what the speaker has said. & 3.80 & 1.076 \\
$\mathbf{2}$ & I make a clarification request when I am not sure what the speaker has said. & 3.78 & .961 \\
$\mathbf{3}$ & I ask the speaker to use easy words when I have difficulties in comprehension. & 3.76 & 1.028 \\
$\mathbf{4}$ & I ask the speaker to slow down when I can't understand what the speaker has & 3.78 & 1.077 \\
& said. & & \\
\hline
\end{tabular}

This finding of the current study is consistent with that of the study conducted by Zulkurnain and Kaur (2014) showing that the category of "negotiation for meaning while listening' strategies has the highest mean score. It can be determined that the students might take risk in communication. They might not fear of being called a 'fool'.
They might not avoid requesting clarification of meaning or repetition of message (Foster \& Ohta, 2005), which may help negotiate meaning, resulting in facilitating second or foreign language acquisition. Negotiating meaning with interlocutors helps students to get unknown language items and use them later in other situations (Rababah \& 
Bulut, 2007); and through employing such strategies for negotiation, students can receive comprehensible input and have opportunities for modifying their output (Nakatani, 2010).

Regarding the use of non-verbal strategies while listening, the data displayed in Table 11 reveal that this category ranks second with $\mathrm{M}=3.67$ and St. $\mathrm{D}=.912$. Like speaking strategies, many students often used gestures and paid attention to the speaker's eye contact, facial expressions and gestures when they had difficulties in listening (item $19 \& 20$ ) with $\mathrm{M}=$ $3.56 \& 3.78$ respectively. The data collected from the focus groups also revealed that 24 respondents (100\%) used gestures when having difficulties in listening. For example, SE-4 reported, "When I don't understand the speaker, I use body languages, gestures, facial expressions, and eye contact."

Table 11. Descriptive statistics and rank of non-verbal strategies while listening

\begin{tabular}{lcccc}
\hline No & Items & Rank & Mean & St. D \\
\hline & Non-verbal strategies while listening & 2 & 3.67 & .912 \\
$\mathbf{1 9}$ & I use gestures when I have difficulties in understanding. & & 3.56 & 1.133 \\
$\mathbf{2 0}$ & I pay attention to the speaker's eye-contact, facial expression and gestures. & 3.78 & 1.049 \\
\hline
\end{tabular}

The finding of the study is in line with that of Ounis (2016) and Chairat (2017) exploring that non-verbal and negotiation of meaning strategies are most frequently used in coping with listening problems. Obviously, the students had difficulties understanding the speaker's messages. Their knowledge of English language might be limited, which hindered their ability to understand what their interlocutors said. It can be said that these findings of the study consolidate the viewpoint of Canale and Swaine (1980), and Nakatani (2010) that show that nonverbal and negotiation for meaning strategies have the effectiveness and usefulness in oral communication.

Ranking third is the category of scanning strategies. The data in Table 12 show that the students often used these strategies to cope with listening problems with $\mathrm{M}=3.59$ and $\mathrm{St}$. $\mathrm{D}=.683$. Among the four strategies, trying to catch the speaker's main point obtained the highest mean score (item 14) with $\mathrm{M}=3.82$. The data collected from the focus groups revealed that students paid attention to the speaker's intonation, intention, main ideas, key words, types of sentences, verbs and subjects of sentences. For instance, some students expressed, "....I pay attention to pronunciation and intonation, subjects, verbs, types of sentence (SO-3); “..... I just pay attention to speakers' intonation and main ideas of the message (JU-4); “....I pay attention to pronunciation, intonation, main ideas, verbs, subjects and types of sentences (SE04)."

Table 12. Descriptive statistics and rank of scanning strategies

\begin{tabular}{|c|c|c|c|}
\hline No & Items & Mean & St. D \\
\hline & Scanning strategies & 3.59 & .683 \\
\hline 11 & I pay attention to the subject and verb of the sentence when I listen. & 3.48 & 1.075 \\
\hline 12 & I especially pay attention to the interrogative when I listen to WH-questions. & 3.48 & 1.114 \\
\hline 13 & I pay attention to the first part of the sentence and guess the speaker's intention. & 3.60 & .923 \\
\hline 14 & I try to catch the speaker's main point. & 3.82 & 1.047 \\
\hline
\end{tabular}

Understanding everything spoken in English is impossible for EFL students, especially when they listen to a native speaker; it might be too difficult for them to understand every single word and sentence that the interlocutors spoke. That is why they might employ 'scanning' 
strategies in order to successfully predict the speaker's intention. This finding is consistent with that of Chairat (2017) confirming that most of the students used these strategies in dealing with listening problems.

Regarding 'fluency-maintaining' strategies, these strategies allow students to focus on the speaker's intonation and pronunciation and sometimes ask questions or ask for examples to overcome difficulties and assist understanding. The data in Table 13 show that these strategies were used by about half of the students. This category of strategies rank $4^{\text {th }}$ among the 7 categories with $\mathrm{M}=3.54$ and St. $\mathrm{D}=.606$. Qualitative data also revealed that among 24 respondents, 16 of them reported that they often tried to avoid communication gaps or overcome difficulties by paying attention to the speaker's rhythm and intonation or asking the speaker to give examples when they did not understand. For example, SO-5 said, "I sometimes don't understand what the speaker says, but I asks him or her to explain, or repeat or give example so that I may understand the message."

Table 13. Descriptive statistics and rank of 'fluency-maintaining' strategies

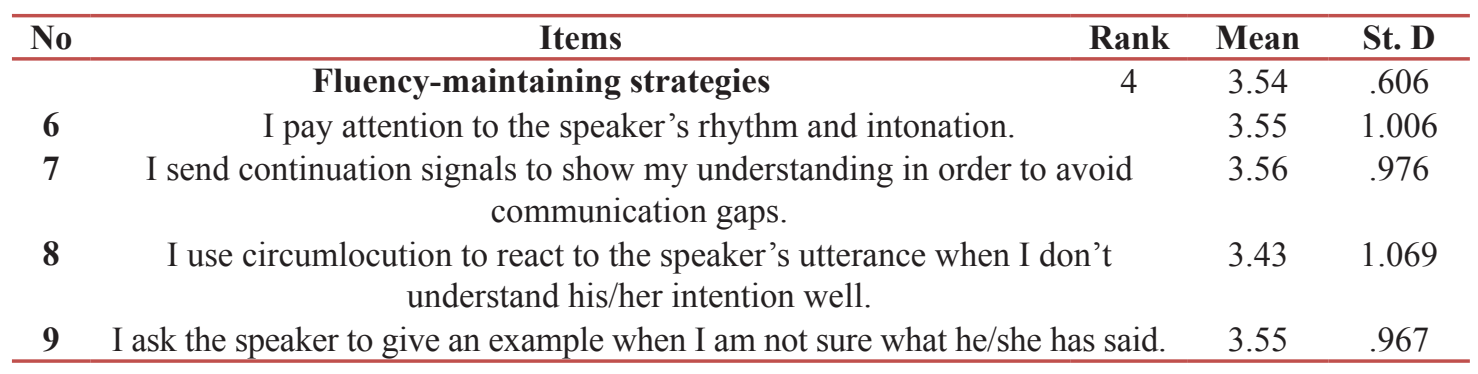

Concerning 'fluency-maintaining' strategies, the findings may imply that about a half of the students employed these strategies in oral communication. It also implied that those students faced difficulties in listening to the speaker. They might lack vocabulary, idioms and grammatical structures, so when the interlocutor used unfamiliar words, they could not understand.

Similarly, the next category of "wordoriented'strategies obtained not very high mean score with $\mathrm{M}=3.53$ and St. $\mathrm{D}=0.677$ (refer to Table 14). It ranks $5^{\text {th }}$ among the 7 listening categories of strategies. The strategies which obtained the higher mean scores are 'paying attention to the words which the speaker slows down or emphasizes.' and 'guessing the speaker's intention by picking up familiar words.' with $\mathrm{M}=3.65$ and 3.61 respectively. Particularly, not many of the students tried to catch every word that the speaker used (item 25) with $\mathrm{M}=3.40$. Qualitative data also revealed that among 24 respondents, 20 of them ( 8 of them are juniors) reported that they often tried to pay attention to familiar words in order to guess the speaker's intention or to types of questions that the interlocutor used. For example, SE-04 said, 'I often pay attention to familiar, common phrases, or expressions and types of questions when I listen to people speaking English, especially he or she is a native speaker.'

Table 14. Descriptive statistics and rank of 'word-oriented' strategies

\begin{tabular}{|c|c|c|c|}
\hline No & Items & Mean & St. D \\
\hline & Word-oriented strategies & 3.53 & 677 \\
\hline 23 & I pay attention to the words which the speaker slows down or emphasizes. & 3.65 & .971 \\
\hline 24 & I guess the speaker's intention by picking up familiar words. & 3.61 & .967 \\
\hline 25 & I try to catch every word that the speaker uses. & 3.40 & 1.075 \\
\hline 26 & I pay attention to the first word to judge whether it is an interrogative sentence or not. & 3.47 & 1.167 \\
\hline
\end{tabular}


This finding of the study is consistent with that of Ounis (2016) discovering that the category of 'word-oriented' strategies also ranked $5^{\text {th }}$. This finding implied that not many of the students used these strategies. That is because they might not be trained how to use these strategies; or these strategies might not be helpful to them. The findings showed that these strategies were used most by sophomores rather than juniors or seniors.

Regarding the category of "getting-thegist' strategies, the data displayed in Table 15 confirm that this category obtained an average mean score with $\mathrm{M}=3.42$ and St. $\mathrm{D}=.639$. However, over half of the students reported that they tried to respond to the speaker even when they did not understand him/ her perfectly with $\mathrm{M}=3.69$ and St. $\mathrm{D}=.667$. Obtaining the lowest mean score $(\mathrm{M}=2.93)$. The finding implied that many students paid attention to whether they understood every word or not. Surprisingly, the qualitative data showed that no respondents reported that they paid attention to every single word.

Table 15. Descriptive statistics and rank of 'getting the gist' strategies

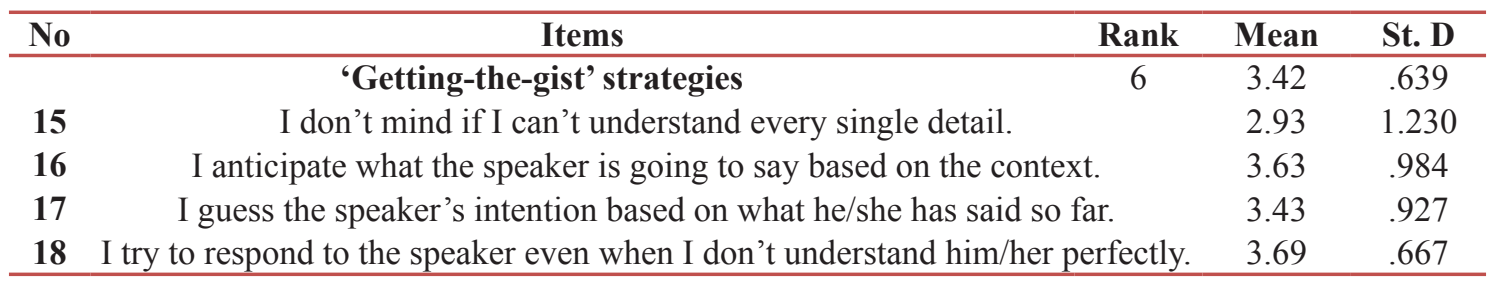

The finding of the study revealed that about $50 \%$ of the students might use these strategies. They might think that it is beneficial for them to develop 'getting-thegist' strategies to optimize their understanding of the words from the context. This finding is consistent with Zulkurnain and Kaur (2014) showing that not many students employed 'getting-the-gist' strategies when listening to people speaking English. The most interesting thing is that without understanding the speaker perfectly, more than half of the students still responded to the speaker. It might be because they wanted to maintain the conversation and tried not to let communication break.
Regarding 'less-active-listener' strategies, the data displayed in Table 16 show that this category of listening strategies obtained the lowest ranking among the 7 categories with $\mathrm{M}=$ 3.03. The students rarely translated into L1 little by little to understand what the speaker had said or rarely only focused on familiar expressions (item $21 \& 22$ ) with $\mathrm{M}=3.03 \& 3.02$ and St. $\mathrm{D}=$ $1.117 \& 1.157$ respectively. The data collected from the focus groups also revealed that not many students employed these strategies when dealing with listening problems. Among 24 students, 21 of them reported that they rarely translated the passage into L1 and 3 of them said that they never translated the passage into L1 when listening to a speaker.

Table 16. Descriptive statistics and rank of 'less-active-listener' strategies

\begin{tabular}{ccccc}
\hline No & Items & Rank & Mean & St. D \\
\hline & 'Less-active-listener' strategies & 7 & 3.03 & .948 \\
$\mathbf{2 1}$ & I try to translate into native language little by little to understand what the & 3.03 & 1.173 \\
& speaker has said. & & \\
$\mathbf{2 2}$ & I only focus on familiar expressions. & 3.02 & 1.157 \\
\hline
\end{tabular}

The two 'less-active-listener' strategies in Table 16 are reduction strategies which might be often used by low proficiency students. This finding of the study is in line with that of Şevki and Oya (2013), Zulkurnain, and Kaur (2014), Ounis (2016) and Chairat (2017) discovering 
that these strategies were employed by only the minority of the students, especially who are less able ones when encountering difficulties in oral communication. It could be concluded that more proficient students do not think these strategies are useful for them to achieve success in dealing with listening problems. Undoubtedly, according to these students, the use of these strategies might not enhance their opportunities to learn English. That is why they have negative attitudes to these strategies.

\subsection{Differences in the use of strategies in oral communication}

Research question 2 attempted to discover whether there are statistically significant differences in the use of strategies among three academic levels.

\subsubsection{Differences in the use of speaking} strategies

To discover if differences existed among academic levels, namely sophomores, juniors, and seniors in the use of the 8 categories of speaking strategies, one-way ANOVA tests were carried out. The data displayed in Table 17 show that the mean scores of three academic levels (sophomore, junior, and senior) for each category of strategies are nearly the same. Nevertheless, based on the mean scores, some interesting findings were discovered. For example, regarding 'social affective strategies', as can be seen in Table 17, juniors sometimes used this category $(\mathrm{M}=3.38)$; meanwhile sophomores and seniors often used this category with $\mathrm{M}=$ 3.60 and 3.50 respectively. With respect to 'accuracy-oriented' strategies, it was found that the three academic levels did not use these strategies very often with $\mathrm{M}=3.18$, $3.19 \& 3.22$ respectively; and especially, obtaining the lowest mean score is "'message abandonment' category of strategies and the mean scores are almost the same, i.e. $\mathrm{M}=2.74$, $2.74 \& 2.75$ respectively. Given that the mean scores of the three academic levels in terms of 8 categories of speaking strategies are nearly the same and that the p-value calculated from the one-way ANOVA tests of all 8 categories of strategies is more than the significance level of 0.05 . It can be seen in Table 18 that the significance values of the 8 categories are $.140, .191, .983, .943, .639, .726, .637, .751$ respectively (i.e., $p=140, .191, .983, .943$, $.639, .726, .637, .751)$. It can be concluded that there were no statistically significant differences among the three academic levels in term of speaking strategies.

Table 17. Descriptive statistics of the use of speaking strategies among the three academic levels $\mathrm{N}=213\left(\mathrm{n}\right.$ of $2^{\text {nd }}$ year level $=75 ; \mathrm{n}$ of $3^{\text {rd }}$ year level $=69 ; \mathrm{n}$ of $4^{\text {th }}$ year level $=69$ )

\begin{tabular}{|c|c|c|c|c|c|c|}
\hline \multirow[t]{2}{*}{ Categories } & \multirow[t]{2}{*}{$\begin{array}{l}\text { Academic } \\
\text { level }\end{array}$} & \multirow[t]{2}{*}{$\mathbf{M}$} & \multirow[t]{2}{*}{ St. D } & \multirow[t]{2}{*}{$\begin{array}{l}\text { Std. } \\
\text { Error }\end{array}$} & \multicolumn{2}{|c|}{$\begin{array}{l}95 \% \text { confidence } \\
\text { interval for mean }\end{array}$} \\
\hline & & & & & Lower bound & Upper bound \\
\hline \multirow{3}{*}{$\begin{array}{l}\text { Social affective } \\
\text { strategies }\end{array}$} & 2nd year & 3.60 & .566 & .065 & 3.47 & 3.73 \\
\hline & 3rd year & 3.38 & .677 & .081 & 3.22 & 3.54 \\
\hline & 4th year & 3.50 & .724 & .087 & 3.33 & 3.68 \\
\hline \multirow[t]{3}{*}{ Fluency-oriented } & 2nd year & 3.76 & .521 & .060 & 3.64 & 3.88 \\
\hline & 3rd year & 3.60 & .704 & .084 & 3.43 & 3.77 \\
\hline & 4 th year & 3.78 & .684 & .082 & 3.62 & 3.95 \\
\hline \multirow[t]{3}{*}{ Negotiation for meaning } & 2nd year & 3.61 & .627 & .072 & 3.46 & 3.75 \\
\hline & 3rd year & 3.61 & .771 & .092 & 3.43 & 3.80 \\
\hline & 4th year & 3.59 & .721 & .086 & 3.42 & 3.76 \\
\hline \multirow[t]{3}{*}{ Accuracy-oriented } & 2nd year & 3.18 & .647 & .074 & 3.03 & 3.33 \\
\hline & 3rd year & 3.19 & .802 & .096 & 2.99 & 3.38 \\
\hline & 4 th year & 3.22 & .602 & .072 & 3.07 & 3.36 \\
\hline
\end{tabular}




\begin{tabular}{|c|c|c|c|c|c|c|}
\hline \multirow{3}{*}{$\begin{array}{l}\text { Message reduction and } \\
\text { alteration }\end{array}$} & 2nd year & 3.60 & .747 & .086 & 3.42 & 3.77 \\
\hline & 3rd year & 3.66 & .765 & .092 & 3.47 & 3.84 \\
\hline & 4th year & 3.71 & .669 & .080 & 3.55 & 3.87 \\
\hline \multirow[t]{3}{*}{ Non-verbal } & 2nd year & 3.52 & .936 & .108 & 3.31 & 3.74 \\
\hline & 3rd year & 3.57 & .920 & .110 & 3.35 & 3.79 \\
\hline & 4th year & 3.64 & .804 & .096 & 3.45 & 3.83 \\
\hline \multirow[t]{3}{*}{ Message abandonment } & 2nd year & 2.74 & .794 & .091 & 2.56 & 2.92 \\
\hline & 3rd year & 2.74 & .807 & .097 & 2.55 & 2.94 \\
\hline & 4th year & 2.75 & .746 & .089 & 2.57 & 2.92 \\
\hline \multirow{3}{*}{$\begin{array}{l}\text { Attempt to think in } \\
\text { English }\end{array}$} & 2nd year & 3.48 & .836 & .096 & 3.28 & 3.67 \\
\hline & 3rd year & 3.39 & .945 & .113 & 3.17 & 3.62 \\
\hline & 4th year & 3.36 & .953 & .114 & 3.14 & 3.59 \\
\hline
\end{tabular}

Table 18. Results of one-way ANOVA tests of the differences in the use of speaking strategies among the three academic levels

$\mathrm{N}=213(\mathrm{n}$ of $2 \mathrm{nd}$ year level $=75 ; \mathrm{n}$ of $3 \mathrm{rd}$ year level $=69 ; \mathrm{n}$ of 4 th year level $=69)$

\begin{tabular}{cccccc}
\hline Categories & Sum of square & df & Mean square & F & Sig. \\
& & & & & \\
\hline Social affective strategies & 1.712 & 2 & .856 & 1.983 & .140 \\
Fluency-oriented & 1.363 & 2 & .681 & 1.668 & .191 \\
Negotiation for meaning & .017 & 2 & .009 & .017 & .983 \\
Accuracy oriented & .056 & 2 & .028 & .059 & .943 \\
Message reduction and & .477 & 2 & .239 & .448 & .639 \\
$\quad$ alteration & .508 & 2 & .254 & .320 & .726 \\
Non-verbal & .439 & 2 & .234 & .441 & .637 \\
Message abandonment & .476 & 2 & .238 & .287 & .751 \\
Attempt to think in English & & & & \\
\hline
\end{tabular}

It can be concluded that many Englishmajored students at HUETCH have enriched their communicative resources. After the first academic year they could employ different strategies to deal with speaking problems. There was evidence that all the three academic levels obtained the similar frequency of the use of strategies in oral communication with mean scores ranging from 3.18 to 3.78 (see Table 18), and that at this stage they might feel more confident so they rarely used "message abandonment" strategies in oral communication with mean scores ranging from 2.74-2.75 (see Table 18).

\subsubsection{Differences in the use of listening} strategies

As regards the use of listening strategies when the three academic levels were compared, the data displayed in Table 19 show that the mean scores of three academic levels (sophomore, junior, and senior) for each category of strategies are nearly the same. It implies that the frequency of the use of listening strategies among the three academic levels were similar with the mean score ranging from 3.46 to 3.80 , which means the three levels often used those strategies except for 'less-activity-listener' strategies which obtained the lowest frequency with $\mathrm{M}=$ $3.04,3.07 \& 2.97$ respectively. Given that the mean scores of the three academic levels in terms of 7 categories of listening strategies are similar and that the p-value calculated from the one-way ANOVA tests of all 7 categories of strategies is more than the significance level of 0.05 . It can be seen in Table 20 that the significance values of the 7 categories 
are $.814, .382, .369, .216, .254, .820, .592$ respectively (i.e., $p=.814, .382, .369, .216$, $.254, .820, .592)$. It can be concluded that there were no statistically significant differences among the three academic levels in term of listening strategies.

Table 19. Descriptive statistics of the use of listening strategies among the three academic levels

$\mathrm{N}=213$ ( $\mathrm{n}$ of $2 \mathrm{nd}$ year level $=75 ; \mathrm{n}$ of $3 \mathrm{rd}$ year level $=69 ; \mathrm{n}$ of 4 th year level $=69$ )

\begin{tabular}{|c|c|c|c|c|c|c|}
\hline \multirow[t]{2}{*}{ Categories } & \multirow[t]{2}{*}{$\begin{array}{l}\text { Academic } \\
\text { level }\end{array}$} & \multirow[t]{2}{*}{ M } & \multirow[t]{2}{*}{ St. D } & \multirow[t]{2}{*}{$\begin{array}{l}\text { Std. } \\
\text { Error }\end{array}$} & \multicolumn{2}{|c|}{$\begin{array}{c}95 \% \text { confidence } \\
\text { interval for mean }\end{array}$} \\
\hline & & & & & Lower bound & Upper bound \\
\hline \multirow[t]{3}{*}{ Negotiation for meaning } & 2nd year & 3.72 & .748 & .086 & 3.55 & 3.89 \\
\hline & 3rd year & 3.76 & .784 & .094 & 3.57 & 3.95 \\
\hline & 4th year & 3.80 & .719 & .086 & 3.63 & 3.97 \\
\hline \multirow[t]{3}{*}{ Fluency-maintaining } & 2nd year & 3.46 & .580 & .066 & 3.33 & 3.60 \\
\hline & 3rd year & 3.59 & .637 & .076 & 3.44 & 3.74 \\
\hline & 4th year & 3.57 & .602 & .072 & 3.43 & 3.72 \\
\hline \multirow[t]{3}{*}{ Scanning } & 2nd year & 3.52 & .667 & .077 & 3.36 & 3.67 \\
\hline & 3rd year & 3.60 & .725 & .087 & 3.43 & 3.77 \\
\hline & 4th year & 3.68 & .655 & .078 & 3.52 & 3.83 \\
\hline \multirow[t]{3}{*}{ Getting-the-gist } & 2nd year & 3.32 & .617 & .071 & 3.17 & 3.46 \\
\hline & 3rd year & 3.47 & .677 & .081 & 3.30 & 3.63 \\
\hline & 4th year & 3.48 & .618 & .074 & 3.34 & 3.63 \\
\hline \multirow[t]{3}{*}{ Non-verbal } & 2nd year & 3.54 & .912 & .105 & 3.33 & 3.75 \\
\hline & 3rd year & 3.79 & .944 & .113 & 3.57 & 4.02 \\
\hline & 4th year & 3.69 & .875 & .105 & 3.48 & 3.90 \\
\hline \multirow[t]{3}{*}{ Less-active-listener } & 2nd year & 3.04 & 1.012 & .116 & 2.80 & 3.27 \\
\hline & 3rd year & 3.07 & .929 & .111 & 2.85 & 3.30 \\
\hline & 4th year & 2.97 & .905 & .108 & 2.76 & 3.19 \\
\hline \multirow[t]{3}{*}{ Word-oriented } & 2nd year & 3.47 & .667 & .077 & 3.31 & 3.62 \\
\hline & 3rd year & 3.57 & .728 & .087 & 3.40 & 3.75 \\
\hline & 4th year & 3.56 & .638 & .076 & 3.41 & 3.71 \\
\hline
\end{tabular}

Table 20. Results of one-way ANOVA tests of the differences in the use of listening strategies among the three academic levels

$\mathrm{N}=213\left(\mathrm{n}\right.$ of $2^{\text {nd }}$ year level $=75 ; \mathrm{n}$ of $3^{\text {rd }}$ year level $=69 ; \mathrm{n}$ of $4^{\text {th }}$ year level $=69$ )

\begin{tabular}{cccccc}
\hline Categories & Sum of squares & df & Mean square & F & Sig. \\
\hline Negotiation for meaning & .232 & 2 & .116 & .206 & .814 \\
Fluency-maintaining & .710 & 2 & .355 & .967 & .382 \\
Scanning & .936 & 2 & .468 & 1.003 & .369 \\
Getting the gist & 1.256 & 2 & .628 & 1.544 & .216 \\
Non-verbal & 2.293 & 2 & 1.147 & 1.381 & .254 \\
Less active listener & .361 & 2 & .180 & .199 & .820 \\
Word-oriented & .485 & 2 & .242 & .526 & .592 \\
\hline
\end{tabular}

The findings of the study revealed no significant differences in the use of listening strategies among the three academic levels as stated above. One more time it may be determined that when entering the second, third or fourth academic years, students have learned different strategies for communication. They not only face difficulties in learning listening comprehension in class but in talking to native speakers in society as well. 
According to Nakatani (2006), highly proficient students try to get intended meaning of the speaker through the use of such strategies as 'scanning', 'getting-the-gist', 'negotiation' and ' non-verbal'. They know how to focus on specific parts of utterance such as verbs, subject, and question types to guess the meaning to support their understanding. Especially, they know how to employ what they have already learned into the process of listening comprehension. It can be said that they are active listeners. Through the use of non-verbal strategies, students of the three levels also know how to compensate their deficient L2 knowledge (Canale \& Swain, 1980; Færch \& Kasper, 1983) in listening.

In conclusion, the aim of research question 2 is to discover whether there are statistically significant differences in the use of both speaking and listening strategies among the three academic levels. Based on the mean scores and the results of the one-way ANOVA tests, it can be reported that there are no statistically significant differences. All the English-majored sophomores, juniors and seniors who participated in the study have similar understanding about communication strategies and how to use those strategies in communication. This finding of the study may reflect similar ways that Vietnamese students use in communication in L1 and in L2, and similar preferences for oral communication strategies in the same culture regardless of individual differences.

\section{Conclusions and recommendations}

The current study aims to explore the most commonly used strategies in oral communication among English majored students, namely sophomores, juniors and seniors, and discover differences in their use of CSs. Based on the findings of the study, it can be concluded that all 8 categories of speaking strategies and 7 categories of listening ones were applied by the students in dealing with English oral communication.
Especially, the most commonly used speaking strategies are "achievement strategies" such as 'fluency-oriented', 'message reduction and alteration', and 'negotiation for meaning while speaking' strategies; and the least commonly used strategies are 'accuracy-oriented' and 'message abandonment'. Meanwhile, regarding listening strategies, the most commonly used strategies are 'negotiation for meaning while listening', 'non-verbal' and 'scanning'; whereas, the least commonly used strategies are 'getting-the-gist' and 'lessactive-listener' strategies. These findings may help determine that the participants of the study have reached a higher proficiency levels compared with the freshmen. These findings are in line with those of Nakatani's (2006). They are more confident in communication; and their knowledge of language has also increased, which helps them communicate rather well in English. More interestingly, the highest mean score of the 8 speaking and 7 listening strategies are 3.72 and 3.76 respectively, which means about $75 \%$ of the students often use these strategies. Regarding the differences in the use of CSs among the three academic students, the findings of the study revealed that there are no significant differences in the use of OCSs among the participants. Nonetheless, the findings of the study imply that English-majored students face problems in communication; and imperfect competence in L2 is unavoidable. That is why they employ strategies not only in learning but also in the use of L2. The most interesting finding of the study is that most of the English-majored students chose the way not to avoid problems but to find out solutions so that breakdowns in communication cannot take place.

English is taught and learned in Vietnam as a foreign language. It is recommended that students should achieve language competence, especially SC so that they will become effective L2 users. Based on the findings of the study, it is therefore recommended that, firstly for EFL teachers, they should be aware 
of different types of OCSs that can be used in L2 communication. In addition, many students may not know about these OCSs, so it is suggested that EFL teachers should explicitly or implicitly introduce, train and encourage them to use OCSs consciously to enhance their ability to encounter difficulties in oral communication. They should create more opportunities in class for students to practice communicating with each other in L2 using OCSs; especially, EFL teachers should know who are less or more able students in their class so that they can show them what strategies should be used and how to use them. With respect to students, as EFL students, they should also be aware of different types of OCSs that can be used in L2 communication. They should practice using OCSs in class so that when communicating with native speakers or foreigners they may easily cope with problems. More importantly, they may be more able to fill the gaps of knowledge, psychology and skills in communication in L2.

As the current study was conducted in only one specific site with the focus on three academic levels of English-majored students, its findings may not be generalizable to other sites. Other studies are recommended to replicate through the use of Nakatani's OCSI (2006) in other universities in Vietnam or in other contexts with English-majored or nonEnglish majored students.

\section{References}

Bachman, L.F. (1990). Fundamental considerations in language testing. Oxford: Oxford University Press.

Bialystok, E. (1983). Some factors in the selection and implementation of communication strategies. In C. Faerch, C., \& Kasper, G. (Eds). Strategies in interlanguage communication (pp.100-118). London: Longman.

Bialystok, E. (1990). Communication strategies: A psychological analysis of second language use. USA: Blackwell Publishers.

Brown, D. H. (2002). Strategies for success: A practical guide to learning English. New York: Longman.

Bulmer, M. (2004). Questionnaires. Thousand Oaks, CA: Sage Publications.
Burns, A. (1999). Collaborative action research for English language teachers. Cambridge: Cambridge University Press.

Canale, M., \& Swain, M. (1980). Theoretical bases of communicative approaches to second language learning \& testing. Linguistics, 1, 1-47.

Canale, M. (1983). From communicative competence to communicative language pedagogy. Language and Communication. London: Longman, 2-27.

Chairat, P. (2017). Oral communication strategies used by English major undergraduates during the internship program. Proceeding of the International Conference on Literature, History, Humanities and Interdisciplinary Studies (LHHISS-17) Bangkok (Thailand) July 11-12.

Chen, H. W. (2009). Oral communication strategies used by English major college students in Taiwan. (Unpublished MA thesis), Chaoyang University of Technology, Taichung, Taiwan.

Corder, S. P. (1983). Error analysis and interlanguage. Oxford: Oxford University Press.

Council of Europe (2001). Common European framework of reference for languages: Learning, teaching and assessment. Cambridge: Cambridge University Press.

Derwing, T. M., \& Munro, M. J. (2015). Pronunciation fundamentals: evidence-based perspectives for L2 teaching and research. Amsterdam: John Benjamins Publishing Company.

Dornyei, Z., \& Scott, M. L. (1995). Communication strategies: An empirical analysis with retrospection. Twenty-first annual symposium of the discrete language and linguistics society (pp. 155-168). Provo: Bringham Young University.

Ellis, R. (1994). The study of second language acquisition. Oxford: Oxford University Press.

Faerch, C., \& Kasper, G. (1983). On identifying communication strategies in interlanguage production. In C. Faerch and G. Kasper (Eds.). Strategies in interlanguage communication (pp.210-238). London: Longman.

Færch, C., \& Kasper, G. (1984). Two ways of defining communication strategies. Language Learning, 34(1), 45-63.

Foster, P., \& Ohta, A. S. (2005). Negotiation for meaning and peer assistance in second language classrooms. Applied Linguistics, 26 (3), 402-430.

Hymes, H. D. (1967). Models of the interaction of language and social setting. Journal of Social Issues, 23(2), 8-28.

Kitajima, R. (1997): Influence of learning context on learners' use of communication strategies. JALT Journal, 19(1), 7-23.

Larsen-Freeman, D., \& Long, M. (1991). An introduction to second language acquisition research. London: Longman.

Leaver, B. L., Ehrman, M., \& Shekhtman, B. ( 2005). Achieving success in second language acquisition. Cambridge: Cambridge University Press. 
Le, H. H. (2018). Students' English communicative skills at the People's Police University in the era of integration. VNU Journal of Foreign Studies, 34(3), 58-74.

Le, H. T. (2013). ELT in Vietnam general and tertiary education from second language education perspectives. VNU Journal of Foreign Studies, 29(1), 65-71.

Littlewood, W. (2011). Communicative language teaching: An expanding concept for a changing world. In E. Hinkel (Ed). Handbook of research in second language teaching and learning: Volume II. (pp. 541-557). London: Routledge.

Maleki, A., (2007). Teachability of communication strategies: An Iranian experience. System 35, 583594.

Mei,A., \& Nathalang, S. S. (2010). Use of communication strategies by Chinese EFL learners. Chinese Journal of Applied Linguistics, 33(3), 110-125.

Mirzaei, A., \& Heidari, N. (2012). Exploring the use of oral communication strategies by (non) fluent L2 speakers. The Journal of Asia TEFL, 9(3),131-156.

Nakatani, Y. (2006). Developing an oral communication strategy inventory. The Modern Language Journal, 90(2), 151-168.

Nakatani, Y. (2010). Identifying strategies that facilitate EFL learners' oral communication: A classroom study using multiple data collection procedures. Modern Language Journal, 94 (1), 116-136.

Ounis, T. (2016). Exploring the use of oral communication strategies by high and low proficiency learners of English: Tunisian EFL students as a case study. International Journal of Humanities and Cultural Studies, 2 (1), 1077-1098.

Peloghitis, J. (2006). Enhancing communication through the use of foreigner interviews. Journal of NELTA, $11(1-2), 47-51$.

Rababah, G. (2002). Second language communication strategies: Definitions, taxonomies, data elicitation methodology and teachability issues. Washington: US Educational Resources Information Center.

Rababah, G. (2004). Strategic competence in an ELT syllabus. ITL. Review of Applied Linguistics. 145-165.

Rababah, G., \& Bulut, D. (2007), Compensatory strategies in Arabic as a second language. Poznan Studies in Contemporary Linguistics, 43(2), 83-106.
Rastegar, M., \& Goha, S. S. M. (2016). Communication strategies, attitude, and oral output of EFL learners: A study of relations. Open Journal of Modern Linguistics, 6, 401-419.

Richards, J. C., \& Schmidt. R.W. Language and communication. London: Longman.

Sevki, K., \& Oya, B. (2013). A comparative evaluation of pre-service English teachers' coping strategies in oral communication. Training and Practice, 11(1-4), 107-124.

Stam, G., \& McCafferty, S.G. (2008). Gesture studies and second language acquisition: A review. In S.G. McCafferty \& G. Stam (Eds). Gesture, second language acquisition and classroom research (pp. 3-24). New York: Routledge.

Stern, H. H. (1983). Fundamental concepts of language teaching. Oxford: Oxford University Press.

Tarone, E. (1980). Communication strategies, a foreigner talk and repair in interlanguage. Language Learning 30, 417-431.

Tarone, E. (1981). Some thoughts on the notion of communication strategy. TESOL Quarterly, 15(3), 285-295.

Tran, T. T. (2013). Factors affecting teaching and learning English in Vietnamese universities. The Internet Journal Language, Culture and Society, 38, 138-145.

Willems, G. M. (1987). Communication strategies and their significance in foreign language teaching. System, 15(3), 351-364.

Yaman, S., \& Özcan, M. (2015). Oral communication strategies used by Turkish students learning English as a foreign language. In M. Pawlak \& E. WaniekKlimczak (Eds.). Issues in teaching, learning and testing speaking in a second language (pp.143-158). New York: Springer.

Zulkurnain, N., \& Kaur, S. (2014). Oral English communication difficulties and coping strategies of diploma of hotel management students at UiTM. 3L: The Southeast Asian Journal of English Language Studies, 20(3), 93-112. 


\title{
CHIẾN LƯợC GIAO TIẾP CỦA SINH VIÊN CHUYÊN NGÀNH TIẾNG ANH
}

\author{
Lê Văn Tuyên, Huỳnh Thị An, Trần Kim Hồng \\ Truờng Đại học Công nghệ TP. Hồ Chí Minh (HUTECH) \\ 475A Điện Biên Phủ, Phường 25 Quận Bình Thạnh-TP. Hồ Chí Minh
}

Tóm tắt: Chiến lược giao tiếp đóng vai trò quan trọng trong quá trình hỗ trợ sinh viên học tiếng Anh nâng cao trình độ và khả năng giao tiếp, giúp giáo viên và sinh viên tiếng Anh nhận thức đầy đủ về những thủ thuật giao tiếp rất cần thiết trong môi trường giáo dục ngoại ngữ ở Việt Nam. Chính vì thế, mục đích của bài nghiên cứu này là khám phá những chiến lược được sử dụng phổ biến nhất trong giao tiếp bằng tiếng Anh của sinh viên trường Đại học Công nghệ Thành phố Hồ Chí Minh-Việt Nam. Nghiên cứu sử dụng cả hai phương pháp định tính và định lượng để thu thập dữ liệu, đó là (1) bảng câu hỏi khảo sát và (2) phỏng vấn theo nhóm. Tổng số 213 sinh viên năm 2 , năm 3 và năm 4 chuyên Anh tham gia vào nghiên cứu. Kết quả của nghiên cứu cho thấy các chiến lược giao tiếp như 'hướng đến sự lưu loát', 'giản lược và thay đổi' và 'thỏa hiệp về nghĩa khi nói’ được sinh viên dùng nhiều nhất khi nói tiếng Anh. Đối với kỹ năng nghe, sinh viên sử dụng nhiều nhất ba chiến lược, bao gồm: 'thỏa hiệp về nghĩa khi nghe', 'lướt ý' và 'phi ngôn ngữ'. Ngoài ra, kết quả của nghiên cứu cũng cho thấy không có sự khác biệt trong cách sử dụng chiến lược giao tiếp bằng lời nói giữa sinh viên năm thứ 2 , thứ 3 và thứ 4 . Bài nghiên cứu hy vọng đóng góp phần nào đó vào quá trình cải thiện năng lưc giao tiếp và khả năng sử dụng những chiến lược giao tiếp để nâng cao kỹ năng tiếng Anh cho sinh viên Đại học HUTECH nói riêng và sinh viên đại học ở Việt Nam nói chung.

Tù khóa: năng lực giao tiếp, chiến lược giao tiếp, sinh viên chuyên Anh, cấp lớp, bối cảnh Việt Nam

\section{APPENDICES}

\section{APPENDIX A: Student questionnaire}

Dear students,

We are conducting a study on oral communication strategies used by English-majored students at HUTECH. Could you please complete the three parts of the questionnaire? Your information provided for us will only be used for the purpose of research so please do not leave any item unanswered.

Thank you very much.

\section{Part 1: Personal information}

1. Your age:

2. Your gender:.

3. Your academic year:.

\section{Part 2: Use of speaking strategies}

In the table below there are 32 English oral communication strategies. How often do you use these strategies in learning? Please read them carefully and circle the responses 1-Never $(\mathbf{N})$, 2-Rarely (R), 3-Sometimes (S), 4-Often (O), or 5-Always (A). 


\begin{tabular}{|c|c|c|c|c|c|c|}
\hline No & Items & $N$ & $R$ & $S$ & $O$ & $A$ \\
\hline \multicolumn{7}{|c|}{ Social affective strategies } \\
\hline 1 & I try to relax when I feel anxious. & 1 & 2 & 3 & 4 & 5 \\
\hline 2 & I try to enjoy the conversation. & 1 & 2 & 3 & 4 & 5 \\
\hline 3 & I try to give a good impression to the listener. & 1 & 2 & 3 & 4 & 5 \\
\hline 4 & I actively encourage myself to express what I want to say. & 1 & 2 & 3 & 4 & 5 \\
\hline 5 & I don't mind taking risks even though I might make mistakes. & 1 & 2 & 3 & 4 & 5 \\
\hline 6 & I try to use fillers when I cannot think of what to say. & 1 & 2 & 3 & 4 & 5 \\
\hline \multicolumn{7}{|c|}{ Fluency-oriented strategies } \\
\hline 7 & I pay attention to my rhythm and intonation. & 1 & 2 & 3 & 4 & 5 \\
\hline 8 & I pay attention to my pronunciation. & 1 & 2 & 3 & 4 & 5 \\
\hline 9 & I pay attention to the conversational flow. & 1 & 2 & 3 & 4 & 5 \\
\hline 10 & I change my way of saying things according to the context. & 1 & 2 & 3 & 4 & 5 \\
\hline 11 & I take my time to express what I want to say. & 1 & 2 & 3 & 4 & 5 \\
\hline 12 & I try to speak clearly and loudly to make myself heard. & 1 & 2 & 3 & 4 & 5 \\
\hline \multicolumn{7}{|c|}{ 'Negotiation for meaning while speaking'strategies } \\
\hline 13 & $\begin{array}{l}\text { I make comprehension checks to ensure the listener understands what } \\
\text { I want to say. }\end{array}$ & 1 & 2 & 3 & 4 & 5 \\
\hline 14 & I repeat what I want to say until the listener understands. & 1 & 2 & 3 & 4 & 5 \\
\hline 15 & While speaking, I pay attention to the listener's reaction to my speech. & 1 & 2 & 3 & 4 & 5 \\
\hline 16 & I give examples if the listener doesn't understand what I'm saying. & 1 & 2 & 3 & 4 & 5 \\
\hline \multicolumn{7}{|c|}{ Accuracy-oriented strategies } \\
\hline 17 & I pay attention to grammar and word order during conversation. & 1 & 2 & 3 & 4 & 5 \\
\hline 18 & I notice myself using an expression which fits a rule that I have learned. & 1 & 2 & 3 & 4 & 5 \\
\hline 19 & I correct myself when I notice that I have made a mistake. & 1 & 2 & 3 & 4 & 5 \\
\hline 20 & I try to emphasize the subject and verb of the sentence. & 1 & 2 & 3 & 4 & 5 \\
\hline 21 & I try to talk like a native speaker. & 1 & 2 & 3 & 4 & 5 \\
\hline \multicolumn{7}{|c|}{ 'Message reduction and alteration'strategies } \\
\hline 22 & I reduce the message and use simple expressions. & 1 & 2 & 3 & 4 & 5 \\
\hline 23 & I use words which are familiar to me. & 1 & 2 & 3 & 4 & 5 \\
\hline 24 & $\begin{array}{l}\text { I replace the original message with another message because of feeling } \\
\text { incapable of executing my original intent. }\end{array}$ & 1 & 2 & 3 & 4 & 5 \\
\hline \multicolumn{7}{|c|}{ Non-verbal strategies while speaking } \\
\hline 25 & I try to make eye contact when I am talking. & 1 & 2 & 3 & 4 & 5 \\
\hline 26 & I use gestures and facial expressions if I can't express myself. & 1 & 2 & 3 & 4 & 5 \\
\hline \multicolumn{7}{|c|}{ 'Message abandonment'strategies } \\
\hline 27 & I leave a message unfinished because of some language difficulty. & 1 & 2 & 3 & 4 & 5 \\
\hline 28 & I ask other people to help when I can't communicate well. & 1 & 2 & 3 & 4 & 5 \\
\hline 29 & I give up when I can't make myself understood. & 1 & 2 & 3 & 4 & 5 \\
\hline 30 & $\begin{array}{l}\text { I abandon the execution of a verbal plan and just say some words when } \\
\text { I don't know what to say. }\end{array}$ & 1 & 2 & 3 & 4 & 5 \\
\hline \multicolumn{7}{|c|}{ 'Attempt to think in English'strategies } \\
\hline 31 & $\begin{array}{l}\text { I think first of a sentence I already know in English and then try to } \\
\text { change it to fit the situation. }\end{array}$ & 1 & 2 & 3 & 4 & 5 \\
\hline 32 & $\begin{array}{l}\text { I think of what I want to say in my native language and then construct } \\
\text { the English sentence. }\end{array}$ & 1 & 2 & 3 & 4 & 5 \\
\hline
\end{tabular}

Part 3: Use of listening strategies 
In the table below there are 26 strategies used to cope with difficulties in listening. How often do you use these strategies? Please read them carefully and circle the responses 1-Never (N), 2-Rarely (R), 3-Sometimes (S), 4-Often (O), or 5-Always (A).

\begin{tabular}{|c|c|c|c|c|c|c|}
\hline No & Items & $N$ & $\boldsymbol{R}$ & $S$ & $\boldsymbol{O}$ & $A$ \\
\hline \multicolumn{7}{|c|}{ 'Negotiation for meaning while listening'strategies } \\
\hline 1 & I ask for repetition when I can't understand what the speaker has said. & 1 & 2 & 3 & 4 & 5 \\
\hline 2 & I make a clarification request when I am not sure what the speaker has said. & 1 & 2 & 3 & 4 & 5 \\
\hline 3 & I ask the speaker to use easy words when I have difficulties in comprehension. & 1 & 2 & 3 & 4 & 5 \\
\hline 4 & $\begin{array}{l}\text { I ask the speaker to slow down when I can't understand what the speaker has } \\
\text { said. }\end{array}$ & 1 & 2 & 3 & 4 & 5 \\
\hline 5 & I make clear to the speaker what I haven't been able to understand. & 1 & 2 & 3 & 4 & 5 \\
\hline \multicolumn{7}{|c|}{ Fluency-maintaining strategies } \\
\hline 6 & I pay attention to the speaker's rhythm and intonation. & 1 & 2 & 3 & 4 & 5 \\
\hline 7 & $\begin{array}{l}\text { I send continuation signals to show my understanding in order to avoid } \\
\text { communication gaps. }\end{array}$ & 1 & 2 & 3 & 4 & 5 \\
\hline 8 & $\begin{array}{l}\text { I use circumlocution to react to the speaker's utterance when I don 't understand } \\
\text { his/her intention well. }\end{array}$ & 1 & 2 & 3 & 4 & 5 \\
\hline 9 & I ask the speaker to give an example when I am not sure what he/she has said. & 1 & 2 & 3 & 4 & 5 \\
\hline 10 & I pay attention to the speaker's pronunciation. & 1 & 2 & 3 & 4 & 5 \\
\hline \multicolumn{7}{|c|}{ Scanning strategies } \\
\hline 11 & I pay attention to the subject and verb of the sentence when I listen. & 1 & 2 & 3 & 4 & 5 \\
\hline 12 & I especially pay attention to the interrogative when I listen to WH-questions. & 1 & 2 & 3 & 4 & 5 \\
\hline 13 & Ipay attention to the first part of the sentence and guess the speaker's intention. & 1 & 2 & 3 & 4 & 5 \\
\hline 14 & I try to catch the speaker's main point. & 1 & 2 & 3 & 4 & 5 \\
\hline \multicolumn{7}{|c|}{ 'Getting-the-gist' strategies } \\
\hline 15 & I don't mind if I can't understand every single detail. & 1 & 2 & 3 & 4 & 5 \\
\hline 16 & I anticipate what the speaker is going to say based on the context. & 1 & 2 & 3 & 4 & 5 \\
\hline 17 & I guess the speaker's intention based on what he/she has said so far. & 1 & 2 & 3 & 4 & 5 \\
\hline 18 & I try to respond to the speaker even when I don't understand him/her perfectly. & 1 & 2 & 3 & 4 & 5 \\
\hline \multicolumn{7}{|c|}{ Non-verbal strategies while listening } \\
\hline 19 & I use gestures when I have difficulties in understanding. & 1 & 2 & 3 & 4 & 5 \\
\hline 20 & I pay attention to the speaker's eye-contact, facial expression and gestures. & 1 & 2 & 3 & 4 & 5 \\
\hline \multicolumn{7}{|c|}{ 'Less-active-listener'strategies } \\
\hline 21 & $\begin{array}{l}\text { I try to translate into native language little by little to understand what the } \\
\text { speaker has said. }\end{array}$ & 1 & 2 & 3 & 4 & 5 \\
\hline 22 & I only focus on familiar expressions. & 1 & 2 & 3 & 4 & 5 \\
\hline \multicolumn{7}{|c|}{ Word-oriented strategies } \\
\hline 23 & I pay attention to the words which the speaker slows down or emphasizes. & 1 & 2 & 3 & 4 & 5 \\
\hline 24 & I guess the speaker's intention by picking up familiar words. & 1 & 2 & 3 & 4 & 5 \\
\hline 25 & I try to catch every word that the speaker uses. & 1 & 2 & 3 & 4 & 5 \\
\hline 26 & $\begin{array}{l}\text { I pay attention to the first word to judge whether it is an interrogative sentence } \\
\text { or not. }\end{array}$ & 1 & 2 & 3 & 4 & 5 \\
\hline
\end{tabular}




\section{APPENDIX B: Questions for focus group interviews}

1. What problems do you often cope with when you speak English to someone inside or outside the classroom?

2. How do you feel whenever you start to speak English to someone?

3. What do you often pay attention to when you speak English to someone (e.g. pronunciation, vocabulary, or grammar)?

4. How do you often speak English? For example, do you speak slowly, quickly, softly or loudly? Do you try to speak as a native speaker?

5. What kinds of expressions do you use when you speak to someone? For example, do you use complex or simple expressions, familiar words or difficult words to express ideas?

6 . What do you do if you speak to someone but he/she seems not to understand what you say?

7. What do you often do if you don't know how to express your ideas? For example, do you use gestures and facial expressions, get eye contact or look away?

8. What will you do if you can't make yourself understood? For example, do you just say some simple words and stop talking, or always try to keep the conversation?

9. Do you often think of what you want to say in Vietnamese first and then make up the English sentence?

10. What problems do you often cope with when you listen to someone speaking English?

11. What do you ask the speaker to do when you don't understand what he/she says? For example, do you ask him or her to clarify the meaning, use easy words, speak slowly or repeat words?

12. What factors of the speaker do you often pay attention to when you listen to her/him? For example, do you pay attention to rhythm, intonation, pronunciation, gestures, intention, main points...? Do you pay attention to the verb, subject, or types of questions?

13. Do you try to guess what the speaker is saying based on the context or his/her attention?

14. What do you often do when you understand a little about what the speaker says? For example, do you stop talking?

15. What do you do to show that you don't understand what the speaker says? For example, do you use gestures, facial expressions, eye-contact, or translate what you hear into Vietnamese little by little?

16. What do you often pay attention when listening to someone speaking English? For example, do you concentrate on familiar words, sentences, types of questions which the speaker emphasizes or do you try to catch every word? 